\title{
MAP3K7 wt Allele
}

National Cancer Institute

\section{Source}

National Cancer Institute. MAP3K7 wt Allele. NCI Thesaurus. Code C51213.

Human MAP3K7 wild-type allele is located within $6 q 16.1-q 16.3$ and is approximately $72 \mathrm{~kb}$ in length. This allele, which encodes mitogen-activated protein kinase kinase kinase 7 protein, is involved in the regulation of various processes such as apoptosis, transcription and the cellular response to environmental stresses. 